\title{
Proximate composition of whole wheat bread prepared with fortification of rice and sorghum flour
}

\author{
Nida Shaikh, Asadullah Marri, Shahzor Gul Khaskheli*, Saghir Ahmed \\ Sheikh and Iftikhar Ahmed Solangi \\ Institute of Food Sciences and Technology, Faculty of Crop Production Sindh Agriculture University-Pakistan \\ *Corresponding author's email: gulkhaskheli5@gmail.com \\ Citation \\ Nida Shaikh, Asadullah Marri, Shahzor Gul Khaskheli, Saghir Ahmed Sheikh and Iftikhar Ahmed Solangi. \\ Proximate composition of whole wheat bread prepared with fortification of rice and sorghum flour. Pure and \\ Applied Biology. Vol. 6, Issue 2, pp412-417. http://dx.doi.org/10.19045/bspab.2017.60041
}

Received: $13 / 12 / 2016$

Revised: $10 / 03 / 2017$

Accepted: 16/03/2017

Online First: 19/03/2017

\section{Abstract}

Present study was conducted to examine the proximate composition of bread samples prepared with different formulations of whole wheat flour (WWF), sorghum flour (SF) and rice flour (RF). For this reason, three different composite flours were developed i.e. F1=100\% WWF, $\mathrm{F} 2=80 \% \mathrm{WWF}, 10 \% \mathrm{SF}$ and $10 \% \mathrm{RF}, \mathrm{F} 3=60 \% \mathrm{WWF}, 20 \% \mathrm{SF}$ and $20 \% \mathrm{RF}$ and were subsequently used for making of fortified bread samples T1, T2 and T3, respectively. The results indicated that protein, ash and crude fiber contents were increased significantly $(\mathrm{p}<0.05)$, while, moisture and fat content were decreased significantly with progressive substitution of whole wheat flour with sorghum and rice flour in $\mathrm{T} 2$ and $\mathrm{T} 3$ in comparison to T1. There was no significant difference ( $p>0.05$ ) was noticed for carbohydrate content. It is concluded from the present study that fortification of bread samples with sorghum and rice flour (T2 and T3) improved the proximate composition of the bread samples in comparison to T1, thus fortified bread samples are also ideal for the consumption purpose.

Keywords: Bread; Whole wheat flour; Sorghum flour; Rice flour and proximate composition

\section{Introduction}

A rapid increase in consumer demand for cereal-based foods is seen in past few decades due to which research methodologies have prompted in recent years to find various ways for their production, to introduce variety in baked goods and to keep quality characteristics as an ideal nutritional food. Cereal grains provide dietary protein and energy thus can prevent malnutrition, specifically protein Energy Malnutrition [1]. The cereal product, particularly bread is a basic part of human diet in many countries from centuries due to its characteristic sensory properties and nutritional quality. Bread wheat is an important variety of wheat in the semi-arid tropics being cultivated in 33 countries of the world [2]. Bread has been regarded for centuries as one of the most popular and staple food product. It is a fermented bakery product which is mainly prepared from wheat flour, yeast, water and salt by a series unit operations including mixing, kneading, shaping, fermentation and baking [3]. Bread prepared from whole wheat is considered to 
be nutritionally poor in proteins and amino acids. In many countries, where wheat is not a major domestic crop efforts can be made to substitute part of the wheat flour by other kinds of available flours to compensate the nutritional properties of baked goods [4]. Wheat flour is a very popular source of food, but its low protein content has made it less suitable for the production of different kinds of baked goods [5]. Wheat flour is excellent source of food for bread making, because of its gluten and gliadin content. However, in the regions where wheat is not grown sufficiently should rely upon composite flours in order to satisfy their demand [6] and for making bakery goods such as bread. It is also true that trend of making special breads made from whole grain flour in combination with other functional ingredients or cereals is increasing day by day [3].

Sorghum (Sorghum bicolor L. Moench) is the king of cereals. It is a chief cereal produce especially for endanger societies providing food for over 500 million consumers in semi-arid tropical areas [7]. The nutrient in sorghum indicates that it is a good source of proteins, carbohydrates, oils, polyunsaturated fatty acid, vitamins and minerals. Wheat is traditionally used for bread making while consumption of sorghum can be increased by mean of replacing wheat flour by sorghum flour. However, rice flour exhibits properties such as the absence of gluten, low levels of sodium, protein, fat and fiber, and high amount of easily digested carbohydrates, which are desirable for certain special diets. It has bland taste, white color, and hypoallergenic properties [8].

The objective of the present study is to improve the nutritional quality of bread by fortification of bread with highly nutritious cereal flours other than wheat flour such as sorghum flour and rice flour and to investigate the proximate composition of these bread samples.

\section{Materials and methods}

The flour of whole wheat, rice, and sorghum along with other ingredients for bread making i.e. instant dry yeast, shortening, baking powder, sugar and salt were procured from the local market of Hyderabad, Sindh. The purchased material was brought to the Bakery Science Laboratory of Institute of Food Sciences and Technology, Sindh Agriculture University, Tandojam for bread making. All the chemicals and reagents utilized for proximate analysis of bread samples were of analytical grade.

\section{Preparation of composite flour samples}

For preparing composite flour samples, the whole wheat flour (WWF) was blended with rice flour (RF) and sorghum flour (SF) according to the combinations mentioned in Table 1. After blending, composite flour samples were packed in polypropylene bags, sealed properly, coded appropriately and refrigerated till bread making.

Table 1. Combination of whole wheat, rice and sorghum flour for the preparation of composite flour samples $(\%)$

\begin{tabular}{|c|c|c|c|}
\hline Composite flour samples & WWF & RF & SF \\
\hline F1 & $100 \%$ & - & - \\
\hline F2 & $80 \%$ & $10 \%$ & $10 \%$ \\
\hline F3 & $60 \%$ & $20 \%$ & $20 \%$ \\
\hline
\end{tabular}

$* \mathrm{WWF}=$ Whole wheat flour, $\mathrm{RF}=$ Rice flour, $\mathrm{SF}=$ Sorghum flour 


\section{Preparation of bread}

The method was used with slight modification to prepare bread samples according to the [9]. For the preparation of bread sample, flour was mixed with other ingredients (Table 2) and kneaded properly using dough mixer for 10-15 minutes to obtain dough. The dough was removed from the dough mixer and distributed into $400 \mathrm{~g}$ of dough pieces. The dough was allowed to ferment for an hour at room temperature $\left(28 \pm 2^{\circ} \mathrm{C}\right)$ in a pan which was covered with the lid. Followed by fermentation, the pan was placed into preheated reel oven for baking at $250^{\circ} \mathrm{C}$ for 30 minutes. After baking, bread loaves were removed from the pan, cooled at room temperature and packed in polyethylene bags after coding. Later on, bread samples were examined for their proximate composition. However, other replicates of bread samples were carried out in a similar way on different days.

Table 2. Formulation of ingredients of bread samples prepared with different proportions of whole wheat, rice and sorghum flour $(\mathrm{g})$

\begin{tabular}{|l|c|c|c|}
\hline \multirow{2}{*}{ Ingredients } & \multicolumn{3}{|c|}{ Bread samples } \\
\cline { 2 - 4 } & $\mathbf{T}_{\mathbf{1}}$ & $\mathbf{T}_{\mathbf{2}}$ & $\mathbf{T}_{\mathbf{3}}$ \\
\hline Whole-wheat flour $\mathbf{( g )}$ & 400 & 320 & 240 \\
\hline Rice flour $(\mathbf{g})$ & 00 & 40 & 80 \\
\hline Sorghum flour $\mathbf{( g )}$ & 00 & 40 & 80 \\
\hline Salt $(\mathbf{g})$ & 10 & 10 & 10 \\
\hline Sugar $(\mathbf{g})$ & 20 & 20 & 20 \\
\hline Fat/Shortening (g) & 60 & 60 & 60 \\
\hline Yeast (g) & 10 & 10 & 10 \\
\hline Water $(\mathbf{m l})$ & 300 & 300 & 300 \\
\hline Total weight of dough $(\mathbf{g})$ & 800 & 800 & 800 \\
\hline
\end{tabular}

Proximate analysis of bread samples

Moisture, ash, crude protein, fat and fiber content were examined according to the methods of [10]. The total soluble solids content was determined according to the method described by [11]. Carbohydrate content $(\%)$ was calculated by difference.

\section{Statistical analysis}

The data obtained was analyzed according to a statistical procedure of computerized statistical package (i.e. Student Edition of Statistics Version 8.1). ANOVA was performed to obtained differences in mean values via Least Significant Difference at $\mathrm{p}<0.05$.

\section{Results and discussion}

The results achieved from the proximate analysis of the bread samples are presented in Figure 1 and 2. The analysis of variance for the present study showed significant differences in proximate composition among all three bread samples at $\mathrm{p}<0.05$. Figure 1 show that moisture content of fortified bread samples remained 25.87, 21.27 and $19.45 \%$ for $\mathrm{T} 1, \mathrm{~T} 2$, and $\mathrm{T} 3$, respectively. This finding clearly shows decreased in moisture content with increasing level of rice and sorghum flour in bread samples. These results pertaining to decrease in moisture content in the present study are in accordance with the findings of [12] and [13], they found the moisture content of the fortified bread samples was decreased by increasing the level of non-wheat flour. Results for protein content showed in the Figure 2, it was found that protein content of bread samples T1, T2 and T3 was 8.45, 9.06 and 11.69 , respectively. The protein content in bread was increased when wheat flour was substituted for rice and sorghum flour in 
fortified bread samples. According to [14] sorghum flour was found to have protein value $14.0 \%$ also [15] recorded that sorghum flour has higher protein content i.e. $15.3 \%$ in white and $15.9 \%$ in reddish-white sorghum as well as baking, had no effect on protein value. This might be due fortification of sorghum flour protein content was increased in both bread samples T2 and T3. Similar trends of results were also obtained by [16] in which protein content of composite bread samples prepared with the substitution of whole wheat flour with soya bean flour was in the range between 8.13 to $12.50 \%$. Further study also conducted by [17] and results increase in protein content of bread samples when flour other than wheat was added to prepare them. The data regarding fat content is given in Figure 1 which remained $6.75,5.57$ and $3.83 \%$ in $\mathrm{T} 1, \mathrm{~T} 2$, and T3, respectively. Sorghum and wheat contain the appreciable quantity of fat in comparison to rice. Decrease in fat content with the addition of rice flour in both fortified bread samples (i.e. T2 and T3) might be due to low in fat content of the rice flour [18]. A significant increase in carbohydrate content can be noticed from the Figure 2. The carbohydrate content of fortified bread samples $\mathrm{T} 1, \mathrm{~T} 2$, and $\mathrm{T} 3$ was $56.56,61.14$ and $61.77 \%$, respectively. The substitution of wheat flour by rice flour could be the major reason of this observation due to fact that rice flour is attributed to high contents of carbohydrate [19]. The ash content (\%) for fortified bread samples is shown in Figure 2. Ash content remained $1.52,1.65$, and $1.80 \%$ for $\mathrm{T} 1, \mathrm{~T} 2$ and $\mathrm{T} 3$, respectively. Here a significant increase in ash content can be seen with the subsequent substitution of wheat flour by sorghum and rice flour. According to the findings of [14] ash content of sorghum flour is more i.e. 2.29in their study. In the present study, a notable enhancement in fiber content of fortified bread samples was noticed which is presented in the Figure 2. Fiber content remained $0.83,1.3$ and $1.44 \%$ in $\mathrm{T} 1, \mathrm{~T} 2$, and $\mathrm{T} 3$, respectively. This increase in fiber content in fortified bread samples might be due to lower fiber content values of wheat flour and rice flour [19] compared to sorghum flour. A similar pattern of improvement in both ash and fiber content was also noticed by $[20,12]$ in bread samples fortified with non-wheat flour.

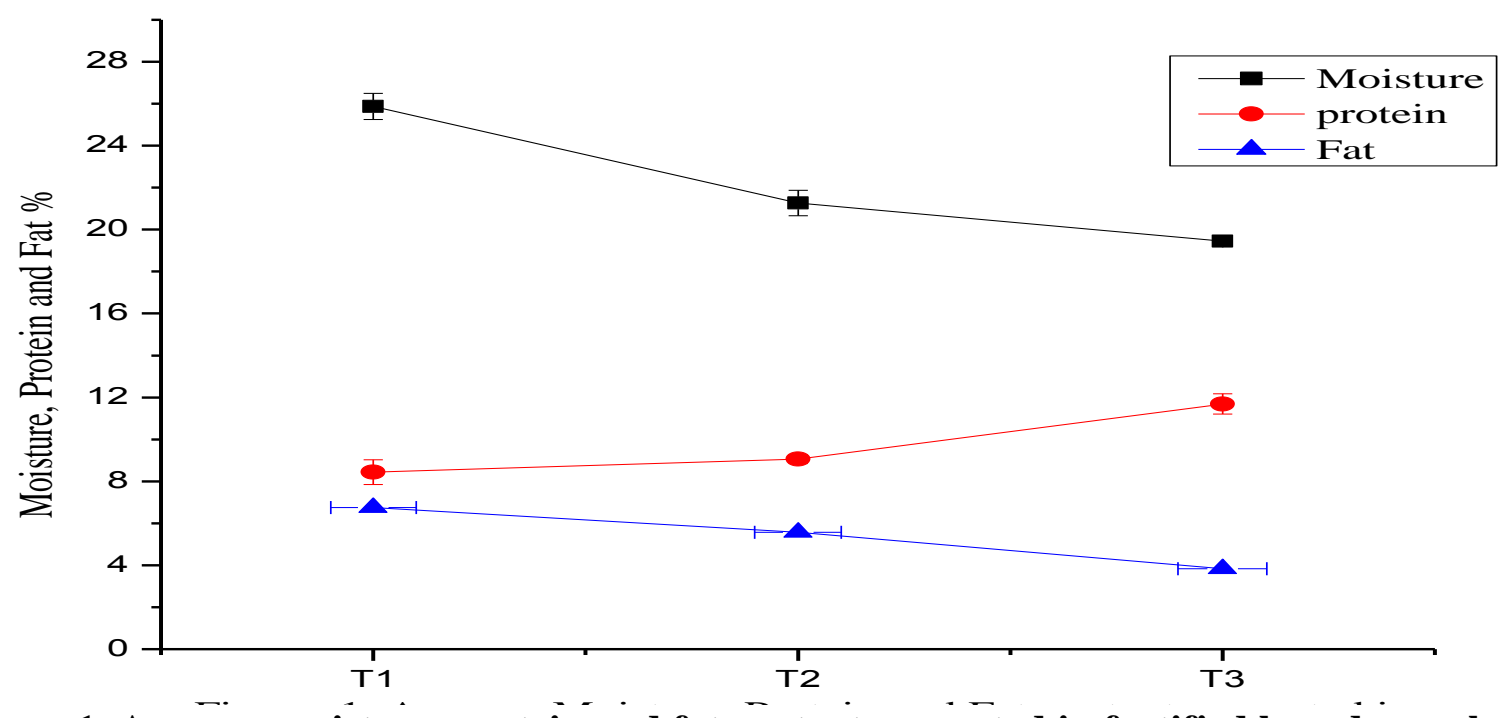

Figure 1. Average moisture, protein and fat content presented in fortified bread samples 


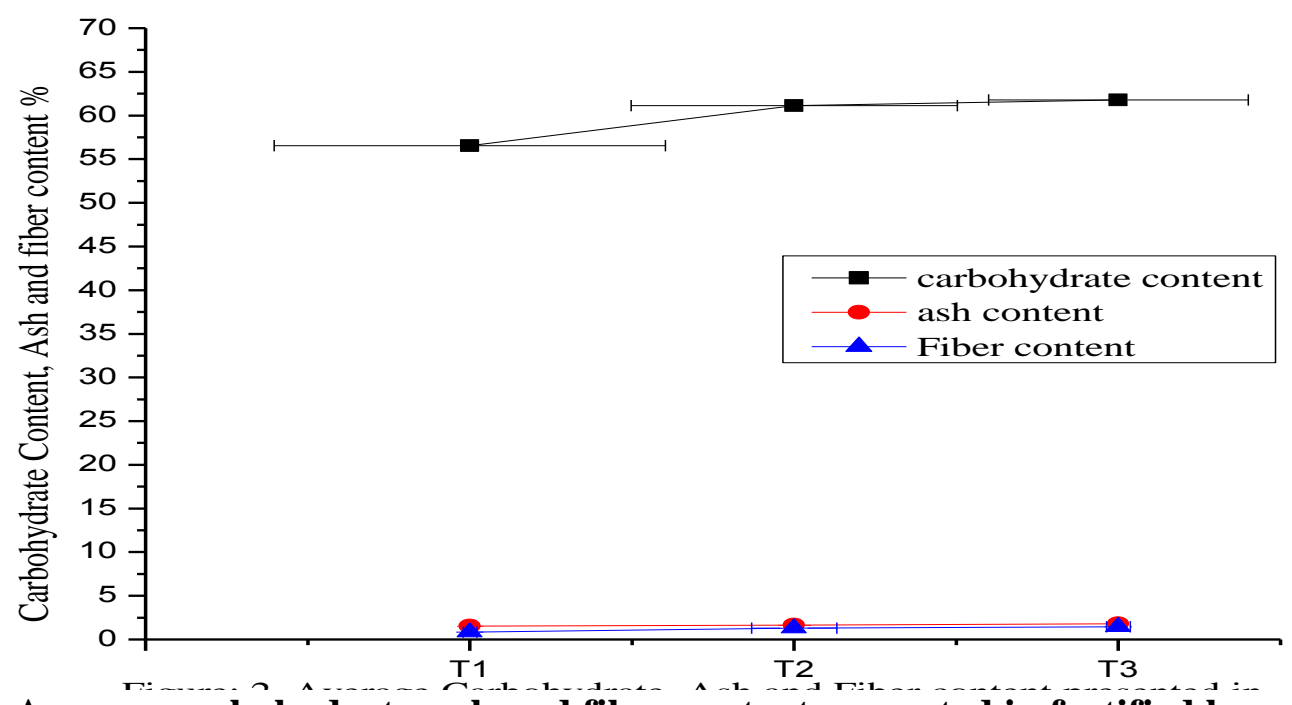

Figure 2. Average carbohydrate, ash and fiber content presented in fortified bread samples

\section{Conclusion}

It is concluded from the present study that fortification of bread samples with sorghum and rice flour (T2 and $\mathrm{T} 3$ ) improved the proximate composition of the bread samples in comparison to $\mathrm{T} 1$, thus fortified bread samples are also ideal for the consumption purpose.

\section{Authors' contributions}

Conceived and designed the experiments: A Marri \& SA Sheikh, Performed the experiments: IA Solangi, Analyzed the data: SG Khaskheli, Contributed reagents/ materials/ analysis tools: N Shaikh, Wrote the paper: N Shaikh \& SG Khaskheli.

\section{References}

1. Bulusu S, Laviolette V, Mannar \& Reddy. (2007). Cereal fortification programmes in developing countries. In: Issues in Complementary Feeding (edited by C. Agostoni \& O. Brunser). Nestec, Basel. Vol 60, pp 91-105

2. Taylor JRN (2004). Grain production and consumption: Africa. In: Encyclopedia of Grain Science (edited by C. Wrigley C, H., Corke H \&, C. E. Walker). pp. 70-78. London: Elsevier.

3. Dewettinck K, Bockstaele VF, Kuhne B, deWalle V, Courtens T \& Gellynck X (2008). Nutritional value of bread:
Influence of processing, food interaction and consumer perception. Rev J Cereal Sci 48: 243-257

4. Hussein A, Kamil MM, Hegazy NA \& ElNor SAH (2013). Effect of wheat flour supplemented with barely and/or corn flour on balady bread quality. Pol. J. Food Nutr 63:121-157.

5. Alpaslan M \& Hayta M (2006). The effects of flaxseed, soy and corn flours on the textural and sensory properties of a bakery product. J Food Qual 29(6): 617-627.

6. Dhingra S \& Jood S (2004). Effect of flour blending on functional, baking and organoleptic characteristics of bread. International J of Food Sci \& Tec 39(2): 213-222.

7. International Crops Research Institute for the Semi-Arid Tropics (ICRISAT) (2009). Sorghum. Available online @ http://www.icrisat.org/sorghum/sorghu m.htm.

8. Gujral HS, Guardiola I, Carbonell JV \& Rosell CM (2003). Effect of cyclodextrinase on dough rheology and bread quality from rice flour. J. Agric. Food Chem. 51(13): 3814-3818.

9. Giami SY, Amasisi T \& Ekiyor G (2004). Comparison of bread mkaing properties 
of composite flour from kernels of roasted and boiled African breadfruit (Treculia Africana decne) seeds. Journal of Raw Material Research 1: $16-25$.

10. AACC (2000). Approved Methods of the Association of American Cereal Chemists. $10^{\text {th }}$ Ed., Minnesota, USA.

11. Mazumdar BC \& Majumder K (2003). Methods on physico-chemical analysis of Fruits. University college of Agriculture, Calcutta University 108109.

12. Mongi RJ, Ndabikunze BK, Chove BE, Mamiro P, Ruhembe CC \& Ntwenya J G (2011). Proximate composition, bread characteristics and sensory evaluation of cocoyam-wheat composite breads. African fr. j. food agric. nutr. dev. 11(7): 5586-5599.

13. Mepba HD, Eboh L \& Nwaojigwa SU (2007). Chemical composition, functional and baking properties of wheat-plantain composite flours. Afr $j$ food agric nutr dev 7(1): 1-22.

14. Awadalkareem AM, Mustafa AI \& Tinay AH (2008). Protein, mineral content and amino acid profile of sorghum flour as influenced by soybean protein concentrate supplementation. Pakistan J Nutr 7(3): 475-479.
15. Khalil JK, Sawaya WN, Safi WJ \& AlMohammad HM (1984). Chemical composition and nutritional quality of sorghum flour and bread. Plant Foods Hum Nutr 34(2): 141-150.

16. Ndife J, Abdulraheem LO \& Zakari U M (2011). Evaluation of the nutritional and sensory quality offunctional breads produced from whole wheat and soya bean flour blends. Afr J Food Sci 5(8): 466-472.

17. Mashayekh M, Mahmoodi MR \& Enterazzi MH (2008). Effect of fortification of defatted soy flour on sensory and rheological properties of wheat bread. International $j$ food sci tech 43: 1693-1698.

18. Gujral HS, Guardiola I, Carbonell JV \& Rosell CM (2003). Effect of cyclodextrinase on dough rheology and bread quality from rice flour. J Agric Food Chem 51: 3814-3818.

19. Da Silva Torres EAF, Garbelotti ML \& Neto JMM (2006). The application of hierarchical clusters analysis to the study of the composition of foods. Food chemistry 99(3): 622-629.

20. Ade-Omowaye BIO, Akinwande BA, Bolarinwa IF \& Adebiyi AO (2008). Evaluation of tigernut (Cyperus esculentus) wheat composite flour and bread. Afr $J$ Food Sci 2: 87-91. 